\title{
Extremely depleted lithospheric mantle and diamonds beneath the southern Zimbabwe Craton
}

\author{
Chris B. Smith ${ }^{1}$, D.Graham Pearson ${ }^{2}$, Galina P. Bulanova ${ }^{3}$, Andrew D. Beard ${ }^{4}$, Richard W. \\ Carlson $^{5}$, Keith Sims ${ }^{6}$, Lovemore Chimuka ${ }^{7}$, Ellah Muchemwa ${ }^{7}$ \\ ${ }^{1}$ Rio Tinto Mining and Exploration Pty. Ltd., London, U.K., \\ ${ }^{2}$ University of Durham, U.K. \\ ${ }^{3}$ University of Bristol, U.K., \\ ${ }^{4}$ Birkbeck College, London, U.K., \\ ${ }^{5}$ Department of Terrestrial Magnetism, Washington, USA, \\ ${ }^{6}$ Rio Tinto Mining and Exploration, Johannesburg, South Africa, \\ ${ }^{7}$ Murowa Diamonds, Harare, Zimbabwe
}

Introduction and geological setting

Mantle xenoliths and diamonds from the $538 \mathrm{Ma}$ Murowa and Sese kimberlites in Zimbabwe (Smith et al., 2004) have been used to characterise the nature of the lithosphere beneath the southern Zimbabwe Craton. These kimberlites lie near the southern edge of the Craton, intruding $2.6 \mathrm{Ga}$ granite batholiths emplaced into the $~ 3.0 \mathrm{Ga}$ Buhwa Greenstone Belt 10-20 km north of the boundary of the Northern Marginal Zone of the late Archean Limpopo Mobile Belt (Fig. 1). The greenstones are believed to rest on non-outcropping $\sim 3.5$ Ga gneissose Tokwe Segment basement.

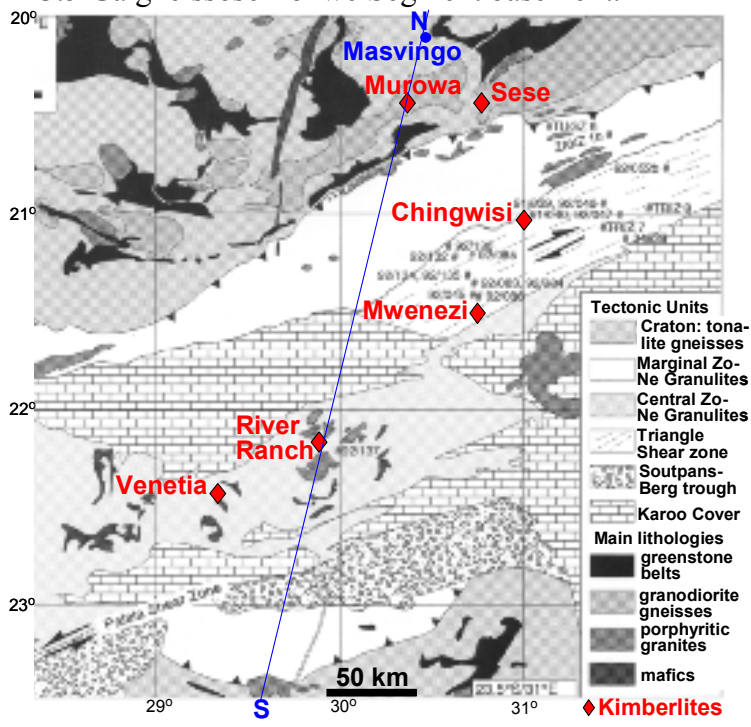

Fig. 1. Geological setting of the Murowa and Sese kimberlites (modified from Kamber et al., 2004).

\section{Mantle xenoliths}

Mantle xenoliths identified are entirely peridotitic with dunite predominating over harzburgite and lherzolite. Textures are coarse granular to porphyroclastic. Some dunites are megacrystic, formed of single crystals of olivine, containing occasional subcalcic chrome pyrope inclusions. Accessory aluminous Cr-spinel is present in vermiform or cuspate shapes suggestive of reequilibration (Fig. 2).

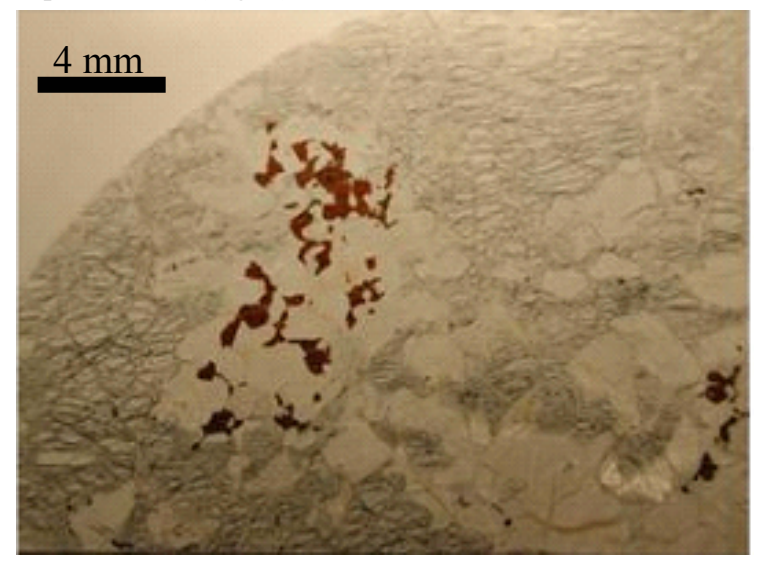

Fig. 2. Sample GP14 (ordinary light): Porphyroclastic, coarse granular, spinel lherzolite from Murowa K1. Pale clinopyroxene and orthopyroxene occur patchily in clots, associated with intergranular, vermiform, chrome spinel (Cr2O3 40\%).

Olivines in the dunites and harzburgites have $\mathrm{mg}$ values of $0.90-0.95$, spanning the average for Kaapvaal craton peridotites (Fig. 3).

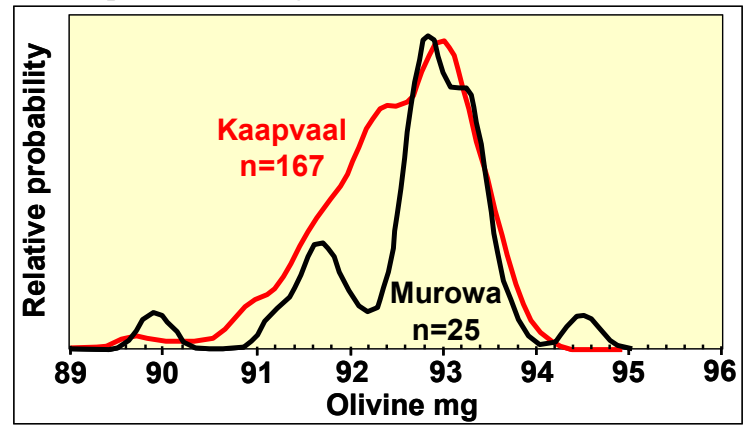

Fig. 3. Olivine mg for Murowa/Sese peridotites 


\section{Diamonds}

The diamonds are of octahedral, transitional and dodecahedral shape, in order of abundance. They are mainly white, pale brown and pale yellow in colour. Most of the crystals have simple octahedral internal growth zonation and blue photoluminescence colour. They contain moderate amounts of nitrogen (60-500 $\mathrm{ppm}$ ) with medium degree of aggregation (40-60\% of 1aB type).

Diamond inclusions are almost entirely peridotitic, with high Cr magnesio-chromite and olivine (fo 0.910.94) predominating over enstatite (mg 0.93-0.96), subcalcic chrome pyrope, Ni-rich sulphide and yimengite. Eclogitic omphacites were recorded in two Murowa diamonds.

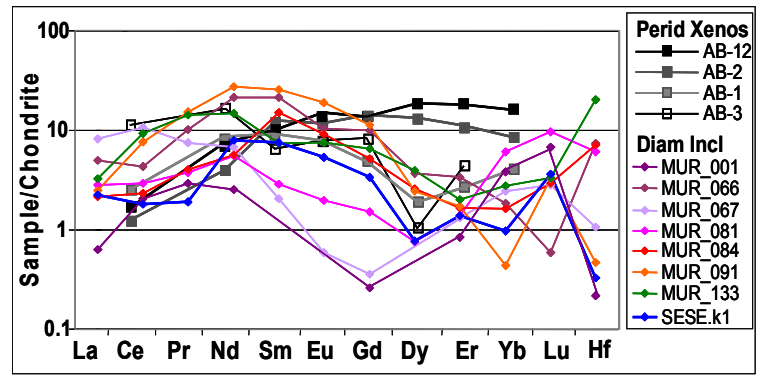

Fig. 4. Chondrite-normalised REE patterns for garnets from Murowa peridotite xenoliths and Murowa and Sese diamond inclusions.

All of the diamond inclusions and two of the peridotite xenoliths (AB1 and AB3) have pyropes with sinusoidal REE patterns depleted in HREE that are typically associated with dunites and harzburgites world wide (Fig. 4). This includes the Ca-rich pyrope from diamond Murowa_133. Two dunite xenoliths (AB12 and AB2) have pyrope with lherzolitic REE patterns, perhaps due to re-fertilisation.

\section{Kimberlite Concentrate Minerals}

Concentrate minerals from the kimberlite are dominated by magnesio-chromite similar in chemistry to diamond inclusion chromites (Fig. 5), and by chrome pyrope (30\% lherzolitic "G9", 70\% subcalcic harzburgitic “G10”) (Fig. 6).

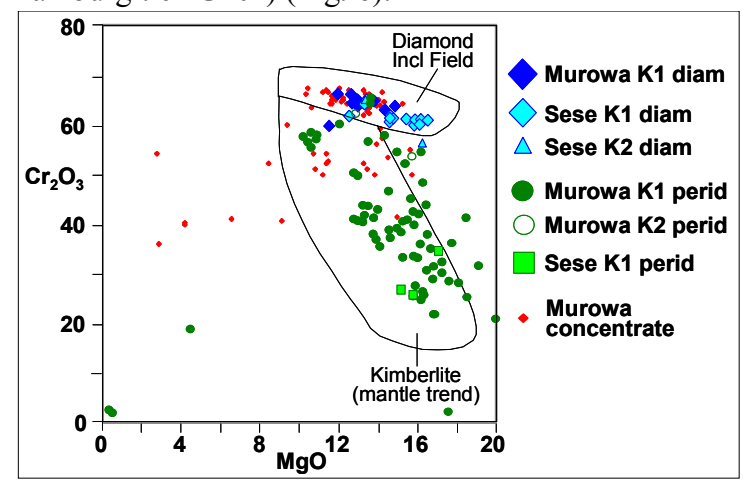

Fig. 5. $\mathrm{MgO}-\mathrm{Cr} 2 \mathrm{O} 3$ plot for chromites from Murowa $\&$ Sese peridotites, diamond inclusions \& concentrates.

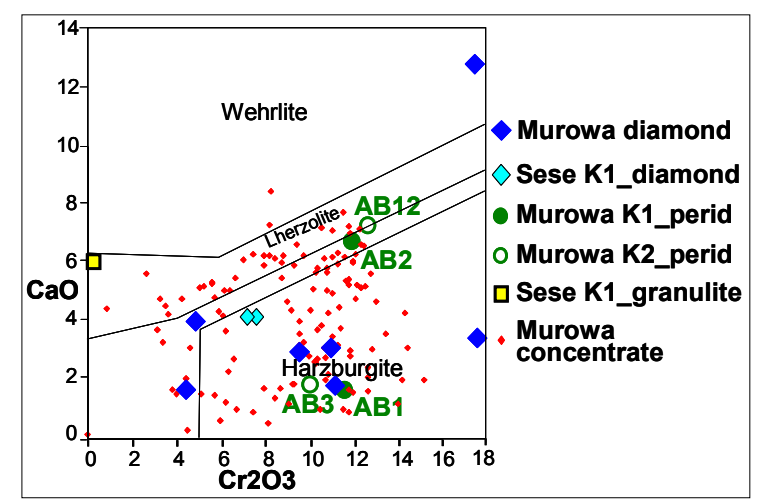

Fig. 7. $\mathrm{Cr} 2 \mathrm{O} 3-\mathrm{CaO}$ plot for garnets from Murowa \& Sese peridotites, diamond inclusions and concentrates.

\section{Peridotite xenolith chemistry}

As expected from their highly depleted mineral chemistry, the Murowa peridotites have bulk compositions that are depleted in magmaphile elements. Their compositions are amongst the most depleted of any cratonic peridotites, with $\mathrm{Ca}$ and $\mathrm{Al}$ contents matched only by the most depleted North Atlantic Craton peridotites (Wittig et al., this volume). $\mathrm{Mg} / \mathrm{Si}$ ratios are very high, in keeping with the olivinerich, orthopyroxene-poor nature of the Murowa peridotites and as such this suite is considerably different from typical low $\mathrm{Mg} / \mathrm{Si}$ peridotites that characterise the Kaapvaal cratonic lithosphere to the South.

The overall impression is therefore of an exceptionally depleted lithospheric mantle beneath the southern Zimbabwe Craton.

\section{Thermobarometry}

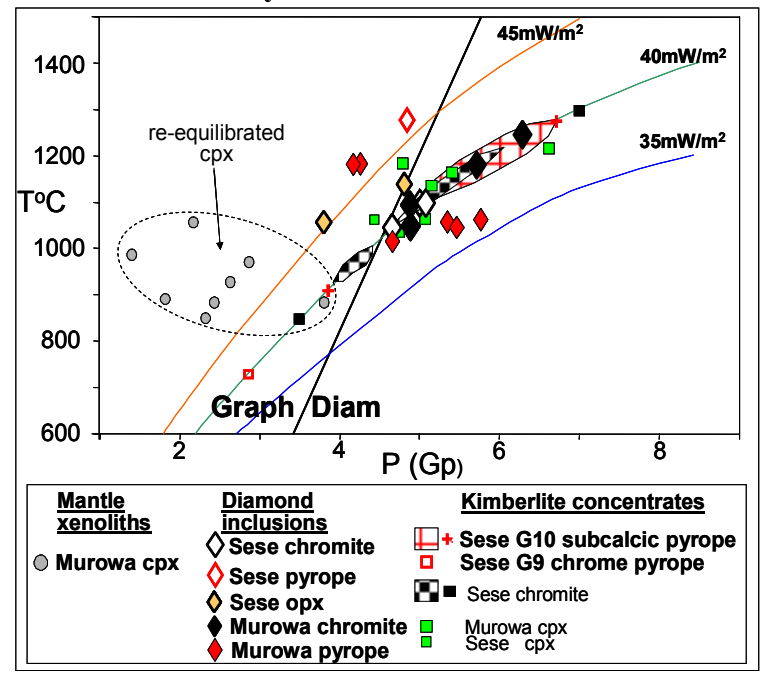

Fig. 8. Thermobarometry/geotherm plot for Murowa/Sese peridotites and diamond inclusions

Pyroxene, garnet and spinel thermobarometry suggests an ambient $40 \mathrm{mWm}^{-2}$ geotherm, with lherzolites coming from shallower depths than dunite-harzburgite assemblages which extend down to $210 \mathrm{~km}$.

Xenolith pyroxenes re-equilibrated at low $\mathrm{P}$ during a metasomatic alteration event, probably during 
kimberlite entrainment. The diamond inclusions typically fall within the temperature range 1030$1250^{\circ} \mathrm{C}$, with median values for garnet and chromite of $\sim 1100^{\circ} \mathrm{C}$. Diamonds seem to be common at top of the mantle section within the diamond stability field rather than towards the lithosphere base.

\section{Dating of peridotites and diamonds}

Whole rock peridotite Re-Os isotope analyses give initial $\gamma$ Os values of between -8.5 and -13 , similar also to Kaapvaal Craton peridotites. Typical minimum TRD ages, of 2.7 to $2.8 \mathrm{Ga}$. are slightly younger in age than the basement greenstone formation but similar to the prominent mode in Re-depletion ages seen in the Kaapvaal craton. In contrast, the average Re-Os model age is $3.2 \mathrm{Ga}$.

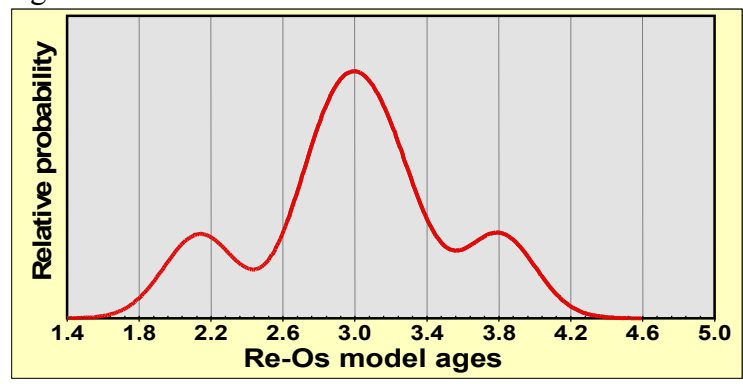

Fig. 9. Re-Os model ages for Murowa peridotite xenoliths

Whole rock Os data gathered so far suggests a model whereby thick lithospheric mantle was stabilised during the early stages of crustal development by shallow peridotite melting required for formation of residues with sufficiently high $\mathrm{Cr} / \mathrm{Al}$ to stabilise chromite which then transforms to low $\mathrm{Ca}$, high $\mathrm{Cr}$ garnet (e.g., Canil, 1992; Stachel et al., 1998). The shallow melting environment is strongly supported by very low whole-rock $\mathrm{Yb}$ concentrations and high Lun/Ybn ratios e.g. Wittig et al. (in revision).

A high Ni, high Os (6.5 ppm Os) sulphide inclusion in diamond of probable peridotitic paragenesis has an initial $\gamma$ Os value (at $533 \mathrm{Ma}$ ) of -16.1 , considerably less radiogenic than the bulk rock peridotites. This sulphide yields a TRD model age of $3.3 \mathrm{Ga}$ and a ReOs age of $3.5 \mathrm{Ga}$, confirming the meso-Archean age for the lithosphere in this region suggested by the Re-Os model ages for the whole rocks. With only a single sample, we cannot accurately estimate the range of diamond formation ages, but the single model age is consistent with the meso-Archean lithosphere formation age indicated by the whole rock data. The moderate $\mathrm{N}$ aggregation of the diamonds at temperatures of $\sim 1100^{\circ} \mathrm{C}$ requires a long mantle residence time, supporting an Archean age of diamond formation.

Comparison with the lithospheric mantle beneath the Limpopo Mobile Belt

Literature review shows that mantle xenoliths, diamonds and concentrate macrocrysts from the Venetia, River Ranch, Mwenezi and Chingwise pipes which intrude the Limpopo Mobile Belt also show strongly depleted peridotitic mantle signatures. Seismic velocity imagery was interpreted by James et al. (2001) to indicate the presence of a deep lithospheric mantle keel beneath the Limpopo Mobile Belt today. The Mobile Belt seems therefore to be a product of thin skin crustal tectonics with the underlying lithospheric mantle linked to that of the southern Zimbabwe Craton and unaffected by these overlying crustal events. We interpret the highly depleted dunite-harzburgite assemblage as a product of shallow melting followed by subduction and accretion beneath the Zimbabwean cratonic crust of the Archean Tokwe Block.

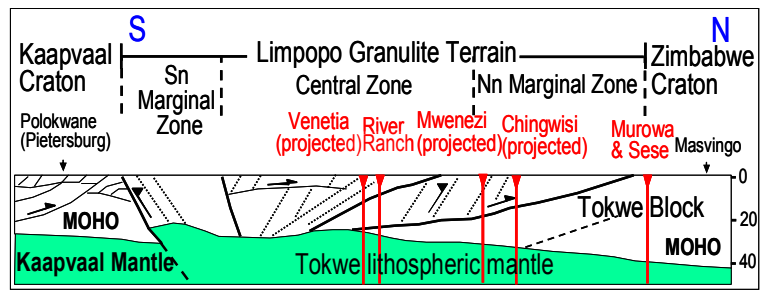

Fig. 10 Illustrative cross section from Limpopo Mobile Belt to southern Zimbabwe Craton (modified from Roering et al., 1992).

\section{References}

Canil, D., 1992. Orthopyroxene stability along the peridotite solidus and the stability of cratonic lithosphere beneath southern Africa. EPSL, 111, 83-95.

James, D.E., Fouch, M.J., VanDecar, J.C., van der Lee, S., \& Kaapvaal Seismic Group, 2001. Tectospheric structure beneath southern Africa. Geophysical Research Letters. 28 (2001), pp. 2485-2488.

Kamber, B., Kramers, J.D. Napier, R. Cliff, R.A. \& Rollinson, H.R. 1994. The Triangle Shear Zone, Zimbabwe. revisited: what remains of the Archaean Limpopo orogeny. Precambrian Research, 70, pp. 191-213.

Roering, C., van Reenen, D.D., Smit, C.A., Barton, J.M., De Beer, J.H., de Wit, M.J., Stettler, J.F., van Schalkwyk, J.F., Stevens, G., \& Pretorius, S., 1992. Tectonic model for the evolution of the Limpopo Belt. Precambrian Research, 55, pp. 539-552.

Smith, C.B., K. Sims, L. Chimuka, A. Duffin, A.D. Beard and R. Townend, 2004. Kimberlite metasomatism at Murowa and Sese pipes, Zimbabwe. Proc. 8th Int. Kimb. Conf., Lithos, Vol. 76, Issues 1-4, pp. 219232.

Stachel, T., Viljoen, K.S., Brey, G., \& Harris, J.W., 1998. Metasomatic processes in lherzolitic and harzburgitic domains of diamondiferous lithospheric mantle: REE in garnets from xenoliths and inclusions in diamonds. Earth Planetary Science Letters, 159, issues 1-2, 112.

Wittig, N., Pearson, D. G., Webb, M., Ottley, C. J., Sand, K.K., Jensen, S. M. and Nowell, G. M., (this volume). Evolution of the mantle root beneath the North Atlantic Craton. 9th International Kimberlite Conference, Frankfurt, Extended Abstract 00267.

Wittig, N., Pearson, D. G., Webb, M., Ottley, C. J., Irvine, G. J., Kopylova, M., Jensen, S. M. and Nowell, G. M., (in revision). Origin of cratonic lithospheric mantle roots: A geochemical study of peridotites from the North Atlantic Craton, West Greenland. Earth and Planetary Science Letters. 